\title{
CHARACTERIZATION OF PROCESSING TOMATO LINES AS THE PHYSIOLOGICAL AND PRODUCTION CHARACTERISTICS
}

\author{
CARACTERIZAÇÃO DE LINHAGENS DE TOMATEIRO INDUSTRIAL QUANTO À \\ CARACTERÍSTICAS FISIOLÓGICAS E DE PRODUÇÃO
}

\author{
Joicy Vitória Miranda PEIXOTO ${ }^{1}$; Luiz Fernandes Cardoso CAMPOS $^{2}$; \\ Emmerson Rodrigues De MORAES ${ }^{3}$; Atalita Francis CARDOSO ${ }^{4}$, \\ Regina Maria Quintão LANA ${ }^{5}$, Abadia dos Reis NASCIMENTO' ${ }^{6}$
}

1. Engenheira Agrônomo, Mestre em Produção Vegetal, Universidade Federal de Uberlândia-UFU, Uberlândia, MG, Brasil. joicyvmpeixoto@yahoo.com.br; 2. Engenheiro Agrônomo, Mestre em Solo e Água, Universidade Federal de Goiás, UFG-EA, Goiânia, GO, Brasil; 3. Professor, Mestre em Solos e Nutrição de Plantas, Universidade Federal de Uberlândia-UFU, Uberlândia, MG, Brasil; 4. Engenheira Agrônomo, Doutorado em Agronomia, Universidade Federal de Uberlândia-UFU, Uberlândia, MG, Brasil; 5. Professora,

Doutora em Fertilidade do Solo e Nutrição de Plantas, Universidade Federal de Uberlândia-UFU, Uberlândia, MG, Brasil; 6. Professora, Doutora em Produção Vegetal, Universidade Federal de Goiás, UFG-EA, Goiânia, GO, Brasil

\begin{abstract}
The tomato crop has social, food, and economic importance both in Brazil and internationally for generating high employment opportunities in the productive sector and offering high nutritional value of the fruits. Given the importance of this tomato culture, there is a constant search for improved varieties that meet the needs of producers in the processing industry. The objective of this study was to characterize strains of the industrial tomato in the absorption of macronutrients and micronutrients, in level of chlorophyll content in leaves, in productivity, and in uniformity of maturation fruits. The experiment was conducted in 2014 in the experimental area of the Federal University of Goiás in Goiânia. The design was a randomized block with 25 treatments (22 lines and three commercial hybrids) and four replications. We evaluated the chlorophyll content in leaves, macronutrient content, foliar macro and micronutrient content, fruit yield, and uniformity of maturation. The lineages CVR 1, CVR 3, CVR4, CVR 5, CVR21, and CVR 22 have high productivity, as well as being uniform in maturation. The lineages CVR 2, CVR 5, CVR 7, CVR 8, CVR 9, CVR 10, CVR 11, CVR 12, CVR 13, CVR 14, CVR 15, CVR 16, CVR 17, CVR 18, CVR 19 and CVR 20 are uniform in maturation. The lines have different potentials regarding the absorption of $\mathrm{P}, \mathrm{K}, \mathrm{Ca}, \mathrm{Mg}$ and $\mathrm{Zn}$. There is a positive correlation between the chlorophyll content and the amount of nitrogen present in the leaves.
\end{abstract}

KEYWORDS: Solanum lycopersicum L. Genotypes. Commercial hybrids. Chlorophyllometer.

\section{INTRODUCTION}

The production of industrial tomatoes (Solanum lycopersicum L.) is classified as an important agribusiness sector not only in Brazil but also in the world. In the world ranking of tomato production, Brazil remained in fourth position 2006 to 2013 with a production of about 4.2 million tons $(\mathrm{t})$, being preceded by China, the United States and Turkey (AGRIANUAL, 2016). According to IBGE (2015) the state of Goiás is the largest producer of tomatoes, followed by the states of Minas Gerais and São Paulo. The average productivity of the tomato in Brazil in 2015 were $63.75 \mathrm{t} \mathrm{ha}^{-1}$. The brazilian regions that contributed most to this figure was the Midwest, Southeast and South with respectively $85.19 \mathrm{t} \mathrm{ha}^{-1}, 68.62 \mathrm{t} \mathrm{ha}^{-1}$ and $57.08 \mathrm{t} \mathrm{ha}^{-1}$ (AGRIANUAL, 2016).

The tomato is a high nutritional requirement vegetable. All the physiological activities of the plant, including nutritional activity, are related to the genetic constitution of plants, as well as to the environment in which they grow (EPSTEIN;
BLOOM, 2006). The production of tomato fruit is maximized when factors such as water, light, $\mathrm{CO}_{2}$, temperature, genotype, nutrition, and cultural practices that influence the growth and development of the culture are considered (SILVA et al., 2012; BASTOS et al., 2013).

The absorption of nutrients by plants occurs according to availability in the soil or as foliar supplementation. Each nutrient has a specific role in plant metabolism. A deficiency or excess of these nutrients become a limiting factor for plant growth (DECHEN; NACHTIGALL, 2007).

The management of soil fertility by the efficient use of lime and fertilizer, among other factors of production, provides a 50\% increase in production and productivity of crops. Other factors relating to intrinsic characteristics of the plant such as genetics, species, cultivar, nutrient absorption efficiency, diseases and pests, allelopathy with other plants, weeds and management practices, also have an influence on productivity and economic return (NOVAIS et al., 2007). 
Chlorophylls are natural photosynthetic pigments responsible for absorbing sunlight to trigger the process of photosynthesis. Chlorophyll "a" and " $\mathrm{b}$ " is present in abundance in green plants (EMRICH et al., 2011). These pigments exert dominant control over the amount of solar radiation absorbed by plants and their concentration in the leaves have close relationship with the photosynthetic rates and the primary productivity of crops (BLACKBURN, 2006). This chlorophyll content in leaves is related to the nutritional status of the plant (FONTES; ARAÚJO, 2007). A deficiency in macronutrients and micronutrients damage the photosynthetic process (KALAJI et al., 2014) and thus predisposes the plant to pests and diseases and reduces the productivity of the crop. Thus, periodic determinations of chlorophyll may assist in the management of the nutritional tomato crop to prevent any deficiency of nutrients essential to plant development.

The introduction of genes, with desirable characteristics such as yield and disease resistance, to get high quality tomato hybrids can be achieved by means of new and diverse genotypes. These are important for success in the breeding program of this culture and consequently in the production of tomato cultivars with high yield and fruit quality (SHAH et al., 2015).

Given this context, the aim of this study was to characterize tomato lines in the absorption of macronutrients and micronutrients in the soil, chlorophyll content, productivity, and uniformity of maturation.

\section{MATERIAL AND METHODS}

The experiment was conducted in the experimental area of the Agronomy School of the Federal University of Goiás, located in the geographical coordinates $16^{\circ} 35^{\prime} 12^{\prime \prime}$ south latitude, 49 $21^{\prime} 14^{\prime \prime}$ West longitude and 730 meters above sea level, with an average annual rainfall of approximately $1487.2 \mathrm{~mm}$. The climate according to Koppen classification is characterized as humid tropical. The soil of the experimental area is classified as Oxisol dystrophic medium texture (EMBRAPA, 2013).

The experimental design was a randomized block with 25 treatments and 4 replications and 22 experimental lines (TRC 1, TRC 2, CVR 3, CVR 4, CVR 5, CVR 6, CVR 7, CVR 8, CVR 9, CVR 10, CVR 11, TRC 12, TRC 13, TRC 14 TRC 15, TRC 16, TRC 17, TRC 18 , TRC 19, TRC 20, TRC 21, and TRC 22) and three commercial hybrids, AP533, SVR-0453 and Kátia, totaling 100 plots. The area of the plot was $22.5 \mathrm{~m}^{2}$, three meters long and 7.5 meters wide. Each plot was six lines with six plants per line for a total of 36 plants per plot. The service area was $12 \mathrm{~m}^{2}$ and composed of four core lines. Irrigation was drip, the amount of water supplied to variable plants according to evapotranspiration of the plants.

Sowing was held on June 5, 2014. The tomato seeds were sown at a depth of $8 \mathrm{~mm}$, using as a substrate a mixture of peat and perlite in the ratio of $300 \mathrm{~L}$ to $120 \mathrm{~L}$ of peat perlite and then the seeds were covered with vermiculite. The soil of the experimental area was prepared by first plowing and then leveling the soil by harrowing. Subsequently, an irrigation dripping system was installed with each dripper flow being $1 \mathrm{~L} \mathrm{~h}^{-1}$. Upon soil analysis (Table 1) it was decided to use $1.0 \mathrm{t} \mathrm{ha}^{-1}$ dolomite and basic 4-30-10 (N-P-K) fertilizer formulation at rate of $1.0 \mathrm{t} \mathrm{ha}^{-1}$. The spacing between plants used was $0.50 \mathrm{~m}$ between rows and $1.5 \mathrm{~m}$. For topdressing $80 \mathrm{~kg} \mathrm{ha}^{-1}$ of ammonium sulfate was applied. This application was split in two times, the first applied at 29 days after transplantation (DAT) and the second at 55 DAT.

The plant chlorophyll content was measured at three plants in the useful area of each plot. The measurements were made in the leaves of the apical part, median part, and basal part of each tomato plant. The analysis was performed at 63 DAT when the plant was in the flowering period and prior to the maturity of the first fruit. The relative chlorophyll content was determined using the ClorofiLOG chlorophyll CFL 1030 model (FALKER, 2008).

Sampling for foliar analysis was performed at the time of flowering as Malavolta et al. (1997), done at 64 DAT by withdrawing the fourth leaf from the apex of the stems of ten plants present in the useful area of each plot. The leaves were placed in paper bags and sent to the laboratory for chemical analysis that was made according to the methodology proposed by Embrapa (2009).

The productivity of fruits was determined after harvest in eight plants of the experimental area. The green, ripe and rotten fruits were weighed separately. After weighing, the data was converted to $\mathrm{tha}^{-1}$.

The character uniform maturation (A) indicating the percentage of mature fruits in relation to total production was determined by the equation $[\mathrm{A}(\%)=(\mathrm{FM} / \mathrm{EN}) * 100] \mathrm{FM}$ where: the production of mature fruits and $\mathrm{EN}$ : the total production of fruit (green + mature).

Data were submitted to analysis of variance and means were compared by the Scott-Knott test at 0.05 significance by Sisvar application 
(FERREIRA, 2011). It has been estimated the Pearson correlation coefficient 0.05 probability by the Student $t$ test, to correlate the leaf nitrogen content variables, leaf chlorophyll content and fruit yield. The Pearson correlation was performed by Assistat application version 7.7 beta (SILVA; AZEVEDO, 2002).

\section{RESULTS AND DISCUSSION}

The CVR 2 line and AP-533 Hybrid resulted in the largest leaf chlorophyll content and the values were respectively 56.86 and 57.42 . The CVR 19, CVR 20, CVR 21 lines had the lowest values for this feature, being 43.41; 46.68 and 44.37, respectively (Table 1).

Table 1. Average Falker chlorophyll index (FCI) in different varieties of industrial tomato.

\begin{tabular}{llll}
\hline Genotypes $^{2}$ & Average $^{1}(\mathrm{FCI})$ & Genotypes $^{2}$ & Average $^{1}(\mathrm{FCI})$ \\
\hline CVR 1 & $50.92 \mathrm{~b}$ & CVR 14 & $49.29 \mathrm{c}$ \\
CVR 2 & $56.86 \mathrm{a}$ & CVR 15 & $50.14 \mathrm{c}$ \\
CVR 3 & $52.71 \mathrm{~b}$ & CVR 16 & $48.69 \mathrm{c}$ \\
CVR 4 & $48.85 \mathrm{c}$ & CVR 17 & $48.35 \mathrm{c}$ \\
CVR 5 & $52.02 \mathrm{~b}$ & CVR 18 & $50.52 \mathrm{~b}$ \\
CVR 6 & $52.60 \mathrm{~b}$ & CVR 19 & $43.41 \mathrm{~d}$ \\
CVR 7 & $51.41 \mathrm{~b}$ & CVR 20 & $46.68 \mathrm{~d}$ \\
CVR 8 & $49.87 \mathrm{c}$ & CVR 21 & $44.37 \mathrm{~d}$ \\
CVR 9 & $51.89 \mathrm{~b}$ & CVR 22 & $49.66 \mathrm{c}$ \\
CVR 10 & $51.14 \mathrm{~b}$ & AP-533 & $57.42 \mathrm{a}$ \\
CVR 11 & $52.87 \mathrm{~b}$ & SVR-0453 & $52.88 \mathrm{~b}$ \\
CVR 12 & $52.74 \mathrm{~b}$ & Kátia & $51.21 \mathrm{~b}$ \\
CVR 13 & $48.79 \mathrm{c}$ & & \\
\hline CV $(\%)$ & & & $\mathbf{5 . 3 1}$ \\
Ks & & & $\mathbf{0 . 1 1}$ \\
F & & & 0.03 \\
F & & & 0.00 \\
\hline
\end{tabular}

${ }^{1}$ Average followed by the same letter in the column do not differ by the Scott-Knott test at 5\% probability. ${ }^{2}$ Lines CVR Plant Breeding and experimental hybrids (AP-533, SVR-0453: Seminis Brazil) and (Kátia: Hazera Seeds). Ks, F, F ': presuppositions of the Kolmogorov-Smirnov test, Levene and additivity blocks; Bold values indicate waste with normal distribution, homogeneous variances and additive effects.

The determination of leaf chlorophyll content is important because the photosynthetic activity of the plant depends in part on the capacity of absorption of light by the leaf. Studies in a wide variety of plants characterized chlorophyll pigments related as equal in the different plants. The apparent differences in vegetable coloring is a result of the presence and variable distribution of associated pigments such as carotenoids, which always accompany the chlorophylls (ELBE, 2000).

Silva et al. (2013) testing the effects of different shading screens in the development and growth of tomato seedlings reported higher chlorophyll index (ICF) in plants under black screen (34.60) and aluminized (32.90). These values are below those observed in this study, where the cultivar AP-533 showed the largest ICF (57.42) and CVR19 lineage lowest ICF (43.41).

It is possible to make some inferences between ClorofiLOG and SPAD, because these portable meters using the same measuring scale (BARBIERI JUNIOR et al., 2012). Ramos (2013) observed at 45 DAT on leaves of tomato plants 'Giuliana', chlorophyll content (SPAD) of 46.20 and 96 DAT, 54.91 ratio. Roosta and Hamidpour (2011) reported the Spad value in aquaponics system, ranging between 28.11 and 30.79 , while in the hydroponic system the variation was from 30.56 to 33.48. These values are below those observed in this study. This difference can be attributed to the different cropping systems, growing season, age of the sampled organ, sample preparation and genotypes.

It was found (Table 2) difference $(\mathrm{p}<0.01)$ in foliar phosphorus $(\mathrm{P})$, potassium $(\mathrm{K})$, calcium $(\mathrm{Ca})$, magnesium $(\mathrm{Mg})$ and sulfur $(\mathrm{S})$ in tomato genotypes evaluated. For nitrogen $(\mathrm{N})$ there was no difference. 
Table 2. Foliar content of macronutrients in different genotypes of industrial tomato.

\begin{tabular}{|c|c|c|c|c|c|c|}
\hline \multirow[b]{2}{*}{ Genotypes $^{2}$} & $\mathrm{~N}$ & $\mathrm{P}^{3}$ & $\mathrm{~K}$ & $\mathrm{Ca}$ & $\mathrm{Mg}$ & $\mathrm{S}$ \\
\hline & \multicolumn{6}{|c|}{$\left(\mathrm{g} \mathrm{kg}^{-1}\right)$} \\
\hline CVR 1 & $30.47 \mathrm{a}^{1}$ & $3.10 \mathrm{a}$ & $31.12 \mathrm{a}$ & $42.47 \mathrm{~b}$ & $10.67 \mathrm{~b}$ & $0.82 \mathrm{~b}$ \\
\hline CVR 2 & $33.62 \mathrm{a}$ & $3.92 \mathrm{a}$ & $30.12 \mathrm{a}$ & $35.82 \mathrm{~b}$ & $9.32 \mathrm{~b}$ & $0.62 \mathrm{~b}$ \\
\hline CVR 3 & $34.52 \mathrm{a}$ & $2.95 \mathrm{a}$ & $36.62 \mathrm{a}$ & $33.47 \mathrm{~b}$ & $9.75 \mathrm{~b}$ & $0.72 b$ \\
\hline CVR 4 & $30.20 \mathrm{a}$ & $3.17 \mathrm{a}$ & $31.62 \mathrm{a}$ & $39.42 \mathrm{~b}$ & $9.05 \mathrm{~b}$ & $0.87 \mathrm{a}$ \\
\hline CVR 5 & $29.80 \mathrm{a}$ & $3.32 \mathrm{a}$ & $33.25 \mathrm{a}$ & $39.70 \mathrm{~b}$ & $10.30 \mathrm{~b}$ & $0.77 \mathrm{~b}$ \\
\hline CVR 6 & $30.12 \mathrm{a}$ & $3.35 \mathrm{a}$ & $32.87 \mathrm{a}$ & $37.02 \mathrm{~b}$ & $9.17 \mathrm{~b}$ & $0.47 \mathrm{~b}$ \\
\hline CVR 7 & $33.62 \mathrm{a}$ & $2.65 \mathrm{~b}$ & $31.87 \mathrm{a}$ & $33.22 \mathrm{~b}$ & $8.62 b$ & $0.62 \mathrm{~b}$ \\
\hline CVR 8 & $31.52 \mathrm{a}$ & $2.85 \mathrm{~b}$ & $31.00 \mathrm{a}$ & $37.95 \mathrm{~b}$ & $10.52 \mathrm{~b}$ & $0.75 \mathrm{~b}$ \\
\hline CVR 9 & $29.77 \mathrm{a}$ & $3.27 \mathrm{a}$ & $25.50 \mathrm{~b}$ & $51.12 \mathrm{a}$ & $11.97 \mathrm{a}$ & $1.20 \mathrm{a}$ \\
\hline CVR 10 & $31.45 \mathrm{a}$ & $2.70 \mathrm{~b}$ & $26.87 \mathrm{~b}$ & $47.45 \mathrm{a}$ & $11.75 \mathrm{a}$ & $1.02 \mathrm{a}$ \\
\hline CVR 11 & $29.67 \mathrm{a}$ & $2.65 \mathrm{~b}$ & $28.87 \mathrm{a}$ & $39.90 \mathrm{~b}$ & $9.90 \mathrm{~b}$ & $0.92 \mathrm{a}$ \\
\hline CVR 12 & $33.35 \mathrm{a}$ & $2.52 b$ & $28.00 \mathrm{~b}$ & $39.95 \mathrm{~b}$ & $11.62 \mathrm{a}$ & $0.75 \mathrm{~b}$ \\
\hline CVR 13 & $32.12 \mathrm{a}$ & $2.62 \mathrm{~b}$ & $28.12 \mathrm{~b}$ & $42.25 \mathrm{~b}$ & $12.02 \mathrm{a}$ & $0.77 \mathrm{~b}$ \\
\hline CVR 14 & $30.55 \mathrm{a}$ & $2.62 \mathrm{~b}$ & $24.37 \mathrm{~b}$ & $48.95 \mathrm{a}$ & $11.85 \mathrm{a}$ & $1.00 \mathrm{a}$ \\
\hline CVR 15 & $29.42 \mathrm{a}$ & $2.72 b$ & $25.62 \mathrm{~b}$ & $49.30 \mathrm{a}$ & $12.90 \mathrm{a}$ & $0.92 \mathrm{a}$ \\
\hline CVR 16 & $31.17 \mathrm{a}$ & $2.77 \mathrm{~b}$ & $29.62 \mathrm{a}$ & $41.95 \mathrm{~b}$ & $10.70 \mathrm{~b}$ & $0.87 \mathrm{a}$ \\
\hline CVR 17 & $27.77 \mathrm{a}$ & $3.30 \mathrm{a}$ & $27.00 \mathrm{~b}$ & $45.30 \mathrm{a}$ & $10.12 b$ & $0.97 \mathrm{a}$ \\
\hline CVR 18 & $30.30 \mathrm{a}$ & $2.50 \mathrm{~b}$ & $26.12 \mathrm{~b}$ & $47.07 \mathrm{a}$ & $10.55 \mathrm{~b}$ & $1.00 \mathrm{a}$ \\
\hline CVR 19 & $27.75 \mathrm{a}$ & $3.25 \mathrm{a}$ & $31.12 \mathrm{a}$ & $41.45 b$ & $10.30 \mathrm{~b}$ & $1.05 \mathrm{a}$ \\
\hline CVR 20 & $28.12 \mathrm{a}$ & $2.77 \mathrm{~b}$ & $29.50 \mathrm{a}$ & $42.62 \mathrm{~b}$ & $10.87 \mathrm{~b}$ & $0.80 \mathrm{~b}$ \\
\hline CVR 21 & $30.75 \mathrm{a}$ & $2.45 \mathrm{~b}$ & $29.75 \mathrm{a}$ & $39.17 \mathrm{~b}$ & $10.45 \mathrm{~b}$ & $0.87 \mathrm{a}$ \\
\hline CVR 22 & $27.67 \mathrm{a}$ & $2.40 \mathrm{~b}$ & $29.87 \mathrm{a}$ & $45.27 \mathrm{a}$ & $10.12 \mathrm{~b}$ & $0.80 \mathrm{~b}$ \\
\hline AP-533 & $31.85 \mathrm{a}$ & $2.60 \mathrm{~b}$ & $25.25 \mathrm{~b}$ & $45.80 \mathrm{a}$ & $11.85 \mathrm{a}$ & $0.70 \mathrm{~b}$ \\
\hline SVR-0453 & $30.02 \mathrm{a}$ & $3.07 \mathrm{a}$ & $27.50 \mathrm{~b}$ & $48.45 \mathrm{a}$ & $10.37 \mathrm{~b}$ & $0.77 \mathrm{~b}$ \\
\hline Kátia & $32.20 \mathrm{a}$ & $2.82 \mathrm{~b}$ & $29.25 \mathrm{a}$ & $35.32 \mathrm{~b}$ & $10.30 \mathrm{~b}$ & $0.75 \mathrm{~b}$ \\
\hline $\mathrm{CV}(\%)$ & 10.41 & 7.65 & 10.50 & 15.69 & 12.53 & 19.49 \\
\hline $\mathrm{Ks}$ & 0.20 & 0.20 & 0.08 & 0.20 & 0.20 & 0.20 \\
\hline $\mathrm{F}$ & 0.04 & 0.01 & 0.14 & 0.02 & 0.78 & 0.27 \\
\hline
\end{tabular}

${ }^{1}$ Average followed by the same letter in the column do not differ by the Scott-Knott test at $5 \%$ probability.

${ }^{2}$ lineage CVR Plant Breeding and experimental hybrids (AP-533, SVR-0453: Seminis Brazil) and (Kátia: Hazera Seeds). ${ }^{3}$ Average transformed by the square root function. Ks, F: presuppositions of the Kolmogorov-Smirnov and Levene tests; Bold values indicate waste with normal distribution and homogeneity of variances.

The difference in accumulated nutrient content of culture is associated mainly with the plant growth stage and genotype. Soil and climatic conditions, interaction between nutrients, light, planting time, relative humidity, diversity of physical, chemical and mineralogical soil, plants conduction system and spacing, also influence the absorption of nutrients.

The CVR 1, CVR 2, CVR 3, CVR 4, CVR 5, CVR 6, CVR 9, CVR 17, CVR 19 lineages and the SVR-0453 hybrid did not differentiate between them in terms of the phosphorus content in the leaves (Table 2). These genotypes had higher $\mathrm{P}$ content in leaves compared the CVR 7, CVR 8, CVR 10,CVR 11 CVR 12, CVR 13, CVR 14,CVR 15, CVR 16, CVR 18, CVR 20, CVR 21, CVR 22 and AP-533 and Kátia hybrids. This difference can be attributed to better rooting the genotypes with high phosphorus content in leaves, thus increasing the absorption.

The strains CVR 1, CVR 2, CVR 3, CVR 4, CVR 5, CVR 6, CVR 7, CVR 8, CVR 11, CVR 16, CVR 19, CVR 2021 CVR, CVR 22 and the hybrid Kátia did not differentiate between them, have the highest levels of $\mathrm{K}$. However, these genotypes were different $(\mathrm{p}<0.05)$ of the strains CVR 9, CVR 1012 CVR, CVR 1314 CVR, CVR 15, CVR 17, CVR 18 and AP-533 hybrid and SVR-0453 (Table 2). These showed a lower content of $\mathrm{K}$ in leaves ranging from 24.37 to $28.12 \mathrm{~g} \mathrm{~kg}^{-1}$. When compared to the first group whose range was 28.87 to $36.62 \mathrm{~g} \mathrm{~kg}^{-1}$. These observed levels are below the nutritional requirement for $\mathrm{K}$ tomato $\left(30-50 \mathrm{~g} \mathrm{~kg}^{-1}\right)$ (EMBRAPA, 2009).

As for the Ca content in the leaves, the lines CVR 9, CVR 10, CVR 14, CVR 15, CVR 17, CVR 18, CVR 22 and AP-533 hybrid and SVR-0453 did 
not differentiate between them, with the highest levels of $\mathrm{Ca}$ when compared to other genotypes. The genotypes CVR 9, CVR 10 , CVR12 CVR, CVR 13, CVR 14, CVR 15 and AP-533 differed from the others, as the $\mathrm{Mg}$ content in the leaves, with the largest content. As for sulfur, the lineages CVR 4 , CVR 9, CVR 10, CVR 11, CVR 14, CVR 15, CVR 16, CVR 17,CVR18, CVR 19, CVR21 showed the highest leaf content, ranging from 0.87 to $1.20 \mathrm{~g} \mathrm{~kg}^{-}$ 1 , while the other genotypes showed levels between $0.47 \mathrm{~g} \mathrm{~kg}^{-1}$ and $0.82 \mathrm{~g} \mathrm{~kg}^{-1}$.

Asri and Sonmez (2012) found the 73 DAS tomato in soilless cultivation, the content of $43.0 \mathrm{~g}$ $\mathrm{kg}^{-1} \mathrm{~N} ; 29.5 \mathrm{~g} \mathrm{~kg}^{-1}$ of $\mathrm{Ca}$ and $6.7 \mathrm{~g} \mathrm{~kg}^{-1} \mathrm{Mg}$ present in the tomato plant leaf. In this work was obtained foliar $\mathrm{Ca}$ and $\mathrm{Mg}$ larger, both elements were above the appropriate standard for $\mathrm{Ca}$ is $14-40 \mathrm{~g} \mathrm{~kg}^{-1}$ and 4-8 $\mathrm{g} \mathrm{kg}^{-1}$ for Mg (EMBRAPA, 2009). Probably this increase was due to lime in order to increase soil base saturation to $80 \%$. The CVR 9 line when compared to other genotypes had the highest calcium content in the leaves, $51.12 \mathrm{~g} \mathrm{~kg}^{-1}$ and CVR 7 the lowest level, which is of $33.22 \mathrm{~g} \mathrm{~kg}^{-1}$. The lineage CVR 15 showed $12.90 \mathrm{~g}^{2}$ magnesium $\mathrm{kg}^{-1}$, which is the highest content when compared to other genotypes. While CVR 7 showed the lowest level, which is $8.62 \mathrm{~g} \mathrm{~kg}^{-1}$.

Betancourt and Pierre (2013) reported in tomato, total uptake by the plant of $0.97 \mathrm{~g}$ of $\mathrm{N}$, $0.358 \mathrm{~g} \mathrm{P}$ and $0.147 \mathrm{~g} \mathrm{~K}$, the largest extraction of these elements carried by the fruit. These authors found a higher calcium and magnesium extraction the leaves respectively corresponding to $0.405 \mathrm{~g}$ and 2.603 g per plant.

Lima et al. (2011) evaluating the foliar concentration of nutrients in tomato plants grown under different substrates and humic acid levels observed average of $7.1 \mathrm{~g} \mathrm{~kg}^{-1}$ sulfur sheets. Even with the application ammonium sulfate cover containing $21 \% \mathrm{~N}$ and $24 \% \mathrm{~S}$, it was found that the $\mathrm{S}$ content obtained in this study were lower, and are not within the standard concentration deemed appropriate for the tomato, 3 to $10 \mathrm{~g} \mathrm{~kg}^{-1}$ (EMBRAPA, 2009). This probably occurred because the sulfur content in the soil $\left(3.4 \mathrm{mg} \cdot \mathrm{dm}^{-3}\right)$ was within the range classified as low (ALVAREZ et al., 1999). Moreover, according to Epstein and Bloom (2006), the leaves usually are often more active in sulfur assimilation of the roots.

The lineages CVR 9, CVR 10, CVR 14 and CVR 15 showed efficiency in the absorption of $\mathrm{N}$, $\mathrm{Ca}, \mathrm{Mg}$ and $\mathrm{S}$. These, except for the CVR 10, demonstrated efficient absorption of micronutrients $\mathrm{B}, \mathrm{Cu}, \mathrm{Fe}, \mathrm{Mn}$ and $\mathrm{Zn}$.
There was found a difference $(\mathrm{p}<0.05)$ in leaf zinc content between the genotypes CVR1, CVR 8, CVR 9, CVR 12, CVR 13, CVR 14, CVR 15, CVR 17, CVR 18, CVR 19, CVR 20, CVR 21 CVR 22, Kátia and CVR 2 genotypes, CVR 3, CVR 4, CVR 5, CVR 6, CVR 7, CVR 10, CVR 11, CVR 16, AP-533, SVR-0453 (Table 3). The first set of genotypes showed the highest leaf $\mathrm{Zn}$ content, ranging from 41.75 to $53.62 \mathrm{mg} \mathrm{kg}^{-1}$, the other genotypes had smaller concentration, ranging from 31.02 to $39.97 \mathrm{~g} \mathrm{~kg}^{-1}$. The CVR 9 lines showed the highest concentration of zinc on the sheet, with an average of $53.62 \mathrm{mg} \mathrm{kg}^{-1}$, while the CVR 6 strain showed the lowest content and $31.02 \mathrm{mg} \mathrm{kg}^{-1}$. However, these values lie within the standard concentration deemed appropriate for tomato is 30$100 \mathrm{mg} \mathrm{kg}^{-1}$ (EMBRAPA, 2009).

The genotypes showed no difference ( $\mathrm{p}>$ 0.05 ) among themselves as to $\mathrm{B}, \mathrm{Cu}, \mathrm{Fe}$ and $\mathrm{Mn}$. Proper foliar B to the tomato crop varies $(30-100$ $\mathrm{mg} \mathrm{kg}{ }^{-1}$ ) (EMBRAPA, 2009). CVR 2 genotypes, CVR 3, CVR 6, 7 CVR, CVR 8, 12 CVR, AP-533 and Kátia showed much lower than recommended. This probably was due to the concentration of boron available in the soil $\left(0.23 \mathrm{mg} \mathrm{dm}{ }^{-3}\right)$ and is classified as low (ALVAREZ et al., 1999). The amount of $\mathrm{Cu}$ and $\mathrm{Fe}$ were observed above the appropriate value, $5-15 \mathrm{mg} \mathrm{kg}^{-1}$ for $\mathrm{Cu}$ and $100-300 \mathrm{mg} \mathrm{kg}^{-1}$ for $\mathrm{Fe}$. According to Alvarez et al. (1999) the content of 4.1 $\mathrm{mg} \mathrm{dm}{ }^{-3} \mathrm{Cu}$ present in the soil is classified as high. While $41.7 \mathrm{mg} \mathrm{dm}^{-3} \mathrm{Fe}$ content is classified as good. Probably the greater availability of these nutrients in the soil favored a greater absorption by the plant. $\mathrm{Mn}$ for all genotypes showed levels within the proper recommendation of $50-250 \mathrm{mg} \mathrm{kg}$ (EMBRAPA, 2009).

Jayakumar et al. (2013) studied the effect of the application of cobalt chloride in tomato crops. The leaves observed in the control treatment value of $41.3 \mathrm{mg} \mathrm{kg}^{-1} \mathrm{Zn}$. Quintero et al. in 2014 reported in tomato shoots an amount of $39 \mathrm{mg} \mathrm{kg}^{-1} \mathrm{Zn}$. While Bressy et al. (2013) observed tomato leaves (CRM $1573 \mathrm{rd}$ ) variation in $\mathrm{Zn}$ content of 24.2 at $32 \mathrm{mg} \mathrm{kg}^{-}$ 1 . The levels obtained in this study corroborate the values found by the authors.

The Kátia, AP-533, SVR-0453 hybrids and lines CVR 1, CVR 3, CVR 4, CVR 5 and CVR 21 CVR22 showed no difference between them, the most productive, with range of $30.54 \mathrm{t} \mathrm{ha}^{-1}$ (Table 4). The lineages CVR 2, CVR 6, CVR 7, CVR 8, CVR 9, CVR 10, CVR 11, CVR 12, CVR 13, CVR14, CVR 15, CVR 16, CVR 17, CVR 18, CVR 19 , and CVR 20 were less productive genotypes, with range of $13.79 \mathrm{tha}^{-1}$. 
Table 3. Levels of micronutrients in leaves of different genotypes of tomato industry.

\begin{tabular}{|c|c|c|c|c|c|}
\hline \multirow[b]{2}{*}{ Genotypes $^{2}$} & $\mathrm{~B}$ & $\mathrm{Cu}$ & $\mathrm{Fe}^{3}$ & $\mathrm{Mn}$ & $\mathrm{Zn}$ \\
\hline & \multicolumn{5}{|c|}{$\left(\mathrm{mg} \mathrm{kg}^{-1}\right)$} \\
\hline CVR 1 & $31.79 \mathrm{a}^{1}$ & $41.34 \mathrm{a}$ & $512.50 \mathrm{a}$ & $109.45 \mathrm{a}$ & $41.87 \mathrm{a}$ \\
\hline CVR 2 & $28.31 \mathrm{a}$ & $40.91 \mathrm{a}$ & $550.87 \mathrm{a}$ & $86.42 \mathrm{a}$ & $33.95 \mathrm{~b}$ \\
\hline CVR 3 & $27.67 \mathrm{a}$ & $41.41 \mathrm{a}$ & $495.85 \mathrm{a}$ & $87.85 \mathrm{a}$ & $36.42 \mathrm{~b}$ \\
\hline CVR 4 & $34.14 \mathrm{a}$ & $46.54 \mathrm{a}$ & $555.92 \mathrm{a}$ & $111.30 \mathrm{a}$ & $38.30 \mathrm{~b}$ \\
\hline CVR 5 & $35.42 \mathrm{a}$ & $40.22 \mathrm{a}$ & $745.87 \mathrm{a}$ & $125.35 \mathrm{a}$ & $36.70 \mathrm{~b}$ \\
\hline CVR 6 & $29.32 \mathrm{a}$ & $43.75 \mathrm{a}$ & $640.52 \mathrm{a}$ & $98.82 \mathrm{a}$ & $31.02 \mathrm{~b}$ \\
\hline CVR 7 & $27.44 \mathrm{a}$ & $47.40 \mathrm{a}$ & $612.40 \mathrm{a}$ & $117.97 \mathrm{a}$ & $31.12 \mathrm{~b}$ \\
\hline CVR 8 & $28.51 \mathrm{a}$ & $43.39 \mathrm{a}$ & $743.02 \mathrm{a}$ & $129.35 \mathrm{a}$ & $42.20 \mathrm{a}$ \\
\hline CVR 9 & $37.26 \mathrm{a}$ & $39.17 \mathrm{a}$ & $461.90 \mathrm{a}$ & $161.87 \mathrm{a}$ & $49.57 \mathrm{a}$ \\
\hline CVR 10 & $30.97 \mathrm{a}$ & $49.39 \mathrm{a}$ & $503.00 \mathrm{a}$ & $99.07 \mathrm{a}$ & $37.97 \mathrm{~b}$ \\
\hline CVR 11 & $32.81 \mathrm{a}$ & $48.24 \mathrm{a}$ & $435.40 \mathrm{a}$ & $102.95 \mathrm{a}$ & $34.90 \mathrm{~b}$ \\
\hline CVR 12 & $29.89 \mathrm{a}$ & $40.07 \mathrm{a}$ & $491.15 \mathrm{a}$ & $97.45 \mathrm{a}$ & $45.42 \mathrm{a}$ \\
\hline CVR 13 & $33.72 \mathrm{a}$ & $36.22 \mathrm{a}$ & $466.72 \mathrm{a}$ & $103.62 \mathrm{a}$ & $45.10 \mathrm{a}$ \\
\hline CVR 14 & $31.46 \mathrm{a}$ & $48.77 \mathrm{a}$ & $462.85 \mathrm{a}$ & $135.90 \mathrm{a}$ & $43.15 \mathrm{a}$ \\
\hline CVR 15 & $32.66 \mathrm{a}$ & $33.77 \mathrm{a}$ & $465.32 \mathrm{a}$ & $113.82 \mathrm{a}$ & $44.70 \mathrm{a}$ \\
\hline CVR 16 & $31.28 \mathrm{a}$ & $33.15 \mathrm{a}$ & $563.02 \mathrm{a}$ & $115.65 \mathrm{a}$ & $39.97 \mathrm{~b}$ \\
\hline CVR 17 & $36.72 \mathrm{a}$ & $41.25 \mathrm{a}$ & $666.97 \mathrm{a}$ & $141.12 \mathrm{a}$ & $44.25 \mathrm{a}$ \\
\hline CVR 18 & $37.04 \mathrm{a}$ & $40.95 \mathrm{a}$ & $637.07 \mathrm{a}$ & $115.35 \mathrm{a}$ & $43.15 \mathrm{a}$ \\
\hline CVR 19 & $33.78 \mathrm{a}$ & $45.86 \mathrm{a}$ & $672.67 \mathrm{a}$ & $149.10 \mathrm{a}$ & $53.62 \mathrm{a}$ \\
\hline CVR 20 & $34,68 \mathrm{a}$ & $49.90 \mathrm{a}$ & $847.87 \mathrm{a}$ & $133.32 \mathrm{a}$ & $46.30 \mathrm{a}$ \\
\hline CVR 21 & $31.17 \mathrm{a}$ & $39.99 \mathrm{a}$ & $404.12 \mathrm{a}$ & $92.35 \mathrm{a}$ & $43.47 \mathrm{a}$ \\
\hline CVR 22 & $34.27 \mathrm{a}$ & $38.84 \mathrm{a}$ & $724.50 \mathrm{a}$ & $117.62 \mathrm{a}$ & $44.12 \mathrm{a}$ \\
\hline AP-533 & $29.59 \mathrm{a}$ & $48.32 \mathrm{a}$ & $587.50 \mathrm{a}$ & $91.67 \mathrm{a}$ & $37.07 \mathrm{~b}$ \\
\hline SVR-0453 & $30.63 \mathrm{a}$ & $42.13 \mathrm{a}$ & $635.30 \mathrm{a}$ & $117.90 \mathrm{a}$ & $38.22 \mathrm{~b}$ \\
\hline Kátia & $27.88 \mathrm{a}$ & $44.69 \mathrm{a}$ & $491.65 \mathrm{a}$ & $135.22 \mathrm{a}$ & $41.75 \mathrm{a}$ \\
\hline $\mathrm{CV}(\%)$ & 18.88 & 20.09 & 15.61 & 32.04 & 18.90 \\
\hline $\mathrm{Ks}$ & 0.06 & 0.002 & 0.04 & 0.07 & 0.01 \\
\hline $\mathrm{F}$ & 0.05 & 0.06 & 0.01 & 0.001 & 0.25 \\
\hline
\end{tabular}

${ }^{1}$ Médias followed by the same letter in the column do not differ by the Scott-Knott test at 5\% probability. ${ }^{2}$ linhagens CVR Plant Breeding and experimental hybrids (AP-533, SVR-0453: Seminis Brazil) and (Kátia: Hazera Seeds). ${ }^{3}$ Average transformed by the square root function. Ks, F: presuppositions of the Kolmogorov-Smirnov and Levene tests; Bold values indicate waste with normal distribution and homogeneity of variances.

Table 4. Average productivity in 25 genotypes of industrial tomato.

\begin{tabular}{llll}
\hline Genotypes $^{2}$ & Average $\left(\mathrm{t} \mathrm{ha}^{-1}\right)$ & Genotypes & Average $\left(\mathrm{t} \mathrm{ha}^{-1}\right)$ \\
\hline CVR 1 & $56.43 \mathrm{a}^{1}$ & CVR 14 & $42.52 \mathrm{~b}$ \\
CVR 2 & $39.51 \mathrm{~b}$ & CVR 15 & $43.89 \mathrm{~b}$ \\
CVR 3 & $58.18 \mathrm{a}$ & CVR 16 & $47.68 \mathrm{~b}$ \\
CVR 4 & $49.62 \mathrm{a}$ & CVR 17 & $38.72 \mathrm{~b}$ \\
CVR 5 & CVR 18 & $46.06 \mathrm{~b}$ \\
CVR 6 & $48.79 \mathrm{a}$ & CVR 19 & $39.72 \mathrm{~b}$ \\
CVR 7 & $33.89 \mathrm{~b}$ & CVR 20 & $37.93 \mathrm{~b}$ \\
CVR 8 & $41.39 \mathrm{~b}$ & CVR 21 & $51.04 \mathrm{a}$ \\
CVR 9 & $46.54 \mathrm{~b}$ & CVR 22 & $55.39 \mathrm{a}$ \\
CVR 10 & $42.14 \mathrm{~b}$ & AP-533 & $55.34 \mathrm{a}$ \\
CVR 11 & $42.93 \mathrm{~b}$ & SVR-0453 & $52.02 \mathrm{a}$ \\
CVR 12 & $42.93 \mathrm{~b}$ & Kátia & $64.43 \mathrm{a}$ \\
CVR 13 & $41.33 \mathrm{~b}$ & - & - \\
\hline CV $(\%)$ & $36.39 \mathrm{~b}$ & - & 16.20 \\
Ks & - & - & $\mathbf{0 . 2 0}$ \\
F & - & - & $\mathbf{0 . 8 2}$ \\
F & - & - & $\mathbf{0 . 0 9}$ \\
\hline
\end{tabular}

${ }^{1}$ Average followed by the same letter in the column do not differ by the Scott-Knott test at 5\% probability. ${ }^{2}$ Lineages CVR Plant Breeding Ltda. Experimental hybrids (AP-533, SVR-0453: Seminis Brazil and Katya: Hazera Seeds). Ks, F, F ': Presuppositions of the Kolmogorov-Smirnov test, Levene and additivity blocks; Bold values indicate waste with normal distribution, homogeneous variances and additive effects. 
Productivity is a polygenic trait, being highly influenced by the environment. The genetic gain obtained for this characteristic is generally lower when compared to a characteristic from simple inheritance (BOITEUX et al., 2012). In this work fertigation was not carried out, which would improve the nutritional balance.

Coimbra et al. (2013) in evaluating the agronomic performance of creeping tomato obtained the productivity of $79.49 \mathrm{t} \mathrm{ha}^{-1}$ in the cultivar IPA-6 and AP-533 the amount of $56.73 \mathrm{t} \mathrm{ha}^{-1}$. The difference in productivity of AP-533 hybrid and the authors in this study (55.34 $\left.\mathrm{t} \mathrm{ha}^{-1}\right)$ was given due to the different fertilizations, the type and soil fertility.

Costa et al. (2011) in evaluating different lines of industrial tomato in an organic system achieved the highest productivity and lower the CLN1621L CLN1621F, these being respectively $36.33 \mathrm{t} \mathrm{ha}^{-1}$ and $20.96 \mathrm{t} \mathrm{ha}^{-1}$. These results are below the values observed in this study, which noted the highest productivity in Kátia hybrid $\left(64.43 \mathrm{t} \mathrm{ha}^{-1}\right)$ followed by the CVR 3 strains ( $58.18 \mathrm{t} \mathrm{ha}^{-1}$ ), CVR 1 (56.43 $\left.\mathrm{t} \mathrm{ha}^{-1}\right)$, VSC 22 (55.39) and the hybrid PA$533\left(55.34 \mathrm{t} \mathrm{ha}^{-1}\right)$. While the lines that scored lower yields were the CVR $6\left(33.89 \mathrm{t} \mathrm{ha}^{-1}\right)$ followed by CVR 13 (36.39 $\left.\mathrm{t} \mathrm{ha}^{-1}\right)$ and CVR 20 (37.93 $\left.\mathrm{tha}^{-1}\right)$.

It was observed a significant positive correlation between chlorophyll content in leaf (LCC) and $\mathrm{N}$ leaf content (LNC). This indicates that a larger amount of nitrogen in leaf promotes increase in chlorophyll content, favoring the photosynthetic process.

Table 5. Matrix of Pearson correlation coefficients of the variables leaf nitrogen content (LNC), leaf chlorophyll content (LCC) and productivity of industrial tomato (Prod.).

\begin{tabular}{llll}
\hline \multicolumn{1}{c}{ Variables } & LNC $\left(\mathrm{g} \mathrm{kg}^{-1}\right)$ & LCC $($ ICF $)$ & Prod. $\left(\mathrm{t} \mathrm{ha}^{-1}\right)$ \\
\hline LNC $\left(\mathrm{g} \mathrm{kg}^{-1}\right)$ & 1 & 0.5214 & 0.1869 \\
LCC $($ ICF $)$ & $* *$ & 1 & 0.1658 \\
Prod. $\left(\mathrm{t} \mathrm{ha}^{-1}\right)$ & $\mathrm{ns}$ & $\mathrm{ns}$ & 1 \\
\hline
\end{tabular}

** Significant at $1 \%$ and not significant NS by Student $t$ test.

According to Cardoso et al. (2011), the knowledge of suitable chlorophyll content allows a diagnosis of $\mathrm{N}$ deficiency, and so through the visual monitoring by the leaf color it is possible to correct the problem in advance.

The uniformity of maturation is an important feature in the breeding selection process of the tomato for industrial processing (BOITEUX et al., 2012). This feature facilitates mechanical harvesting (PIOTTO; PERES, 2012).

It was observed a difference $(\mathrm{p}<0.01)$ between the genotypes analyzed for uniformity of maturation. Most genotypes $\mathrm{A}$, and the CVR 1 lineages, CVR 3, 4 CVR, 21 CVR, CVR 22, and AP-533 hybrid and Kátia had lower values for this characteristic when compared to other genotypes (Figure 1).

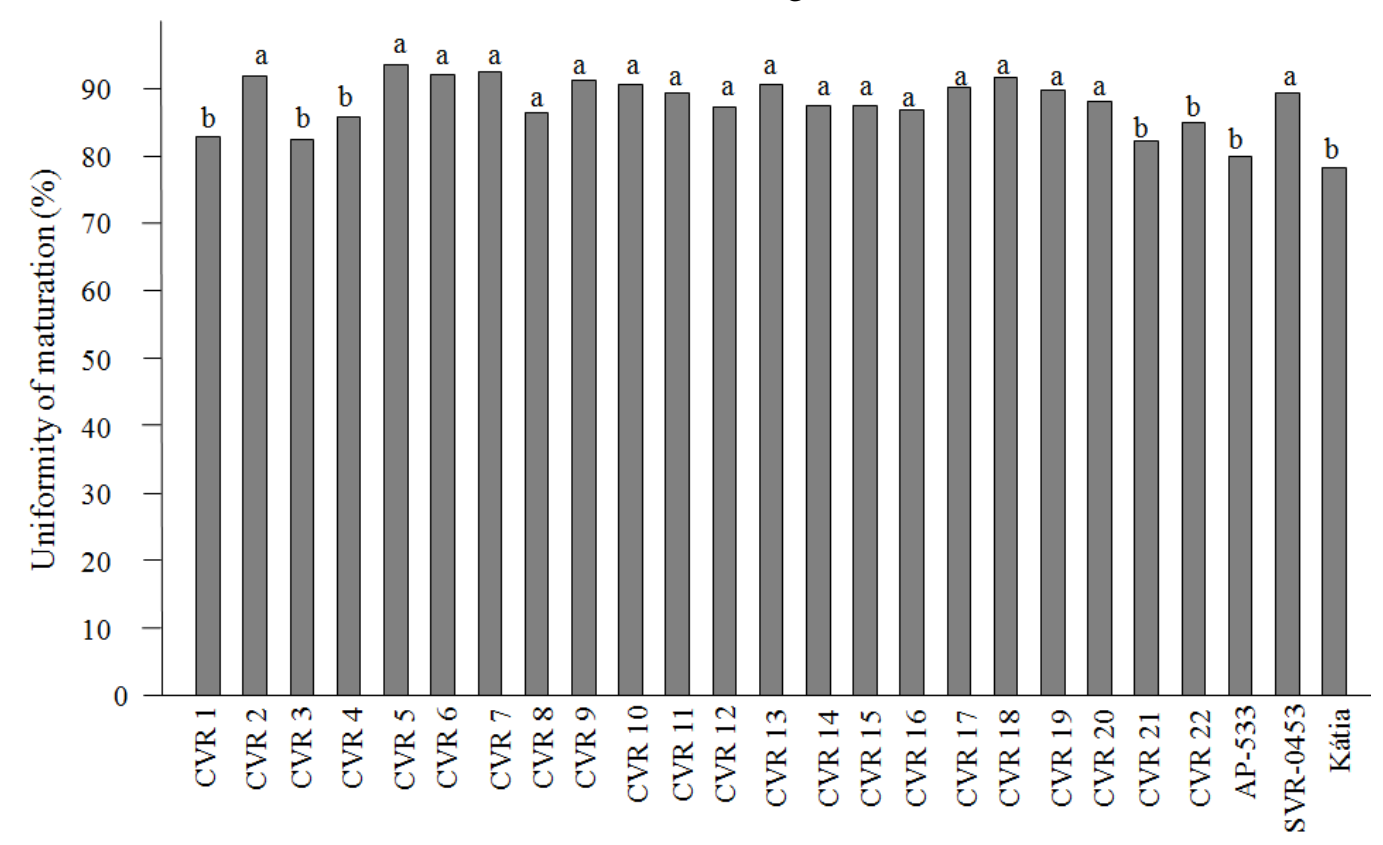

Genotypes 
Figure 1. Uniformity of maturation in industrial tomato genotypes. Aragão et al. (2004) evaluated different hybrids of industrial tomato found in most A 'TEH26', which is $94.56 \%$ and the lowest value of $79.94 \%$ in the hybrid 'TEH-13'. In this work the CVR 5 line reached the highest point $\mathrm{A}$, which is 93.55\% while the hybrid Katya reached the lowest A, whose value was $78.19 \%$.

\section{CONCLUSIONS}

The lineages CVR 2, CVR 5, CVR 7, CVR 8, CVR 9, CVR 10, CVR 11, CVR 12, CVR 13, CVR 14, CVR 15, CVR 16, CVR 17, CVR 18, CVR 19 and CVR 20 are uniform in maturation.

The lines have different potentials regarding the absorption of $\mathrm{P}, \mathrm{K}, \mathrm{Ca}, \mathrm{Mg}$ and $\mathrm{Zn}$.

The lines CVR 1, CVR 3, CVR 4, CVR 5, CVR 21 and CVR 22 are suitable for the genetic improvement of the tomato, presenting high productivity.

There is a positive correlation between the chlorophyll content and the amount of nitrogen present in the leaves.

\section{ACKNOWLEDGMENT}

The authors thank CVR Plant Breeding, the field staff of the Federal University of Goiás, Bayer CropScience and Capes for the support given.

RESUMO: A cultura do tomateiro possui importância social, alimentar e econômica tanto no cenário brasileiro quanto no internacional pela alta empregabilidade do setor produtivo e alto valor nutritivo dos frutos. Diante da relevância da cultura, é constante a busca por cultivares melhoradas que atendam as necessidades dos produtores, bem como das indústrias de processamento. Objetivou-se com este trabalho caracterizar linhagens de tomateiro industrial quanto à absorção de macronutrientes e micronutrientes, teor de clorofila, produtividade e uniformidade de maturação. $\mathrm{O}$ experimento foi conduzido no ano de 2014, em área experimental da Universidade Federal de Goiás, em Goiânia. O delineamento foi em blocos casualizados com 25 tratamentos (22 linhagens e três híbridos comerciais) e quatro repetições. Foram avaliados o teor de clorofila presente nas folhas, teores de macro e micronutrientes foliares, produtividade de frutos e a uniformidade de maturação. As linhagens CVR 1, CVR 3, CVR 4, CVR 5, CVR 21 e CVR 22 apresentam alta produtividade, além de serem uniformes quanto a maturação. As linhagens CVR 2, CVR 5, CVR 7, CVR 8, CVR 9, CVR 10, CVR 11, CVR 12, CVR 13, CVR 14, CVR 15, CVR 16, CVR 17, CVR 18, CVR 19 e CVR 20 são uniformes na maturação. As linhagens têm potenciais diferentes quanto à absorção de $\mathrm{P}, \mathrm{K}, \mathrm{Ca}, \mathrm{Mg}$ e Zn. Há uma correlação positiva entre o teor de clorofila e a quantidade de nitrogênio presente nas folhas.

PALAVRAS-CHAVE: Solanum lycopersicum L. Genótipos Híbridos comerciais. Clorofilômetro.

\section{REFERENCES}

AGRIANUAL. Anuário da Agricultura Brasileira: Tomate. 21. ed. São Paulo: Informa economics FNP, 2016. 470p.

ALVAREZ, V. V. H.; NOVAIS, R. F.; BARROS, N. F.; CANTARUTTI, R. B.; LOPES, A. S. Interpretação dos resultados das análises de solos. In: RIBEIRO, A. C.; GUIMARÃES, P. T. G.; ALVAREZ V., V. H. (Ed.). Comissão de fertilidade do solo do Estado de Minas Gerais. Recomendações para o uso de corretivos e fertilizantes em Minas Gerais - $5^{\circ}$ Aproximação. Viçosa: Sociedade Brasileira de Ciência do Solo, 1999. p. 2532.

ARAGÃO, F. A. S.; GIORDANO, L. B.; MELO, P. C. T; BOITEUX, L. S. Desempenho de híbridos experimentais de tomateiro para processamento industrial nas condições edafo-climáticas do cerrado brasileiro. Horticultura Brasileira, Brasília, v. 22, n. 3, p. 529-533, 2004. http://dx.doi.org/10.1590/S010205362004000300005

ASRI, F. O.; SONMEZ, S. Effects of different potassium and iron levels on seasonal changes of nutrient concentrations of tomato plant grown in soilless culture. African Journal of Agricultural Research, Kenya, v. 7, n. 1, p. 28-33, 2012. http://dx.doi.org/10.5897/AJAR11.1119 
BARBIERI JUNIOR, E.; ROSSIELLO, R. O. P.; SILVA, R. V. M. M., RIBEIRO, R. C., MORENZ, M. J. F. Um novo clorofilômetro para estimar os teores de clorofila em folhas do capim Tifton 85. Ciência Rural, Santa Maria, v. 42, n. 12, p. 2242-2245, 2012.

BASTOS, A. R. R.; ALVARENGA, M. A. R.; CARVALHO, J. G.; PINHO, P. J. Nutrição mineral e adubação. In: ALVARENGA, M. A. R. (Ed.). Tomate produção em campo, casa de vegetação e hidroponia. Lavras: Editora Universitária de Lavras, 2013. p. 63-130.

BETANCOURT, P.; PIERRE F. Macronutrient uptake for tomato crop (Solanum lycopersicum Mill var. Alba) under greenhouse conditions, at Quibor, Lara State, Venezuela. Bioagro, Venezuela, v. 25, n. 3, p. 181-188, 2013.

BLACKBURN, G. A. Hyperspectral remote sensing of plant pigments. Journal of Experimental Botany, Oxford, v. 58, n. 4, p. 855-867, 2006. https://doi.org/10.1093/jxb/erl123

BOITEUX, L. S.; FONSECA, M. E. de N.; GIORDANO, L. de B.; DE MELO, P. C. T. Melhoramento genético. In: CLEMENTE, F. M. V. T.; BOITEUX, L. S. (Ed.). Produção de tomate para processamento industrial. Brasília: Embrapa, 2012. p. 31-50.

BRESSY, F. C.; BRITO, G. B.; BARBOSA, I. S.; TEIXEIRA, L. S. G.; KORN, M. G. A. Determination of trace element concentrations in tomato samples at different stages of maturation by ICP OES and ICP-MS following microwave-assisted digestion. Microchemical Journal, New York, v. 109, p. 145-149, 2013. http://dx.doi.org/10.1016/j.microc.2012.03.010

CARDOSO, A. D.; ALVARENGA, M. A. R.; MELO, T. L.; VIANA, A. E. S.; MATSUMOTO, S. N. Índice SPAD no limbo foliar da batateira sob parcelamentos e doses de nitrogênio e potássio. Revista Ciência Agronômica, Ceará, v. 42, n. 1, p. 159-167, 2011. https://doi.org/10.1590/S1806-66902011000100020

COIMBRA, K. das G.; PEIXOTO, J. R.; SANTIM, M. R.; NUNES, M de S. Efeito de produtos alternativos no desempenho agronômico de tomate rasteiro. Bioscience Journal, Uberlândia, v. 29, n. 1, p. 1508-1513, 2013.

COSTA, C. A.; SILVA, A. C.; SAMPAIO, R. A.; MARTINS, E. R. Productivity of determinate growth tomato lines tolerant to heat under the organic system. Horticultura Brasileira, Brasília, v. 29, n. 4, p. 590593, 2011. http://dx.doi.org/10.1590/S0102-05362011000400024

DECHEN, A. R.; NACHTIGALL, G. R. Elementos requeridos à nutrição de plantas. In: NOVAIS, R. F.; ALVARES V., V. H.; BARROS, N. F.; FONTES, R. L. F.; CANTARUTTI, R. B.; NEVES, J. C. L. (Ed.). Fertilidade do solo. Viçosa: Sociedade Brasileira de Ciência do Solo, 2007. p. 92-132.

ELBE, J. H. von. Colorantes. In: FENNEMA, O. W. (Ed.). Química de los alimentos. Zaragoza: Wisconsin, 2000. p. 782-799.

EMBRAPA. Empresa Brasileira de Pesquisa Agropecuária. Manual de análises químicas de solos, plantas e fertilizantes. 2 ed. rev. e ampliada. Brasília: Embrapa informação tecnológica, 2009. 627p.

EMBRAPA. Empresa Brasileira de Pesquisa Agropecuária. Sistema brasileiro de classificação de solos. 3. ed. Brasília: Embrapa, 2013. 353 p.

EMRICH, E. B.; De SOUZA, R. J.; De LIMA, A. A.; FIGUEIREDO, F. C.; SILVA, D. R. G. Cultivo do tomateiro em substratos orgânicos sob aplicação foliar de silicato de potássio em ambiente protegido. Ciência e Agrotecnologia, Lavras, v. 35, n. 1, p. 56-61, 2011. http://dx.doi.org/10.1590/S1413-70542011000100006

EPSTEIN, E.; BLOOM, A. J. Nutrição mineral de plantas: princípios e perspectivas. 3 ed. Londrina: Planta, 2006. 403p. 
FALKER, Automação agrícola. Manual do medidor eletrônico de teor clorofila (ClorofiLOG/CFL 1030). Porto Alegre, 2008. 33p. Disponível em: <http://www.falker.com.br/produto-clorofilog-medidorclorofila.php>. Acesso em: 01 dez. 2016.

FERREIRA, D. F. Sisvar: a computer statistical analysis system. Ciência e Agrotecnologia, Lavras, v. 35, n. 6, p. 1039-1042, 2011. http://dx.doi.org/10.1590/S1413-70542011000600001

FONTES, P. C. R.; ARAÚJO, C. Adubação nitrogenada de hortaliças: Princípios e práticas com o tomateiro. 1. ed. Viçosa: Universidade Federal de Viçosa, 2007. 148 p.

IBGE. Instituto brasileiro de Geografia e Estatística. Levantamento sistemático da produção Agrícola: pesquisa mensal de previsão e acompanhamento das safras agrícolas no ano civil. Fundação Instituto Brasileiro de Geografia e Estatística. Rio de Janeiro, v. 29, n. 5, p. 1-76, mai. 2015.

JAYAKUMAR, K.; RAJESH, M.; BASKARAN, L.; VIJAYARENGAN, P. Changes in nutritional metabolism of tomato (Lycopersicon esculentum Mill.) plants exposed to increasing concentration of cobalt chloride. International Journal of Food Nutrition and Safety, Galati, v. 4, n. 2, p. 62-69. 2013.

KALAJI, H. M.; OUKARROUM, A.; ALEXANDROV, V.; KOUZMANOVA, M.; BRESTIC, M.; ZIVCAK, M.; SAMBORSKA, I. A.; CETNER, M. D.; ALLAKHVERDIEV, S. I.; GOLTSEV, V. Identification of nutrient deficiency in maize and tomato plants by in vivo chlorophyll a fluorescence measurements. Plant Physiology and Biochemistry, Paris,v. 81, p. 16-25, 2014. http://dx.doi.org/10.1016/j.plaphy.2014.03.029

LIMA, A. A.; ALVARENGA, M. A. R.; RODRIGUES, L.; CARVALHO, J.G. Concentração foliar de nutrientes e produtividade de tomateiro cultivado sob diferentes substratos e doses de ácidos húmicos.

Horticultura Brasileira, Brasília, v.29, n. 1, p. 63-69, 2011. https://doi.org/10.1590/S010205362011000100011

MALAVOLTA, E.; VITTI, G. C.; OLIVEIRA, S. A. Avaliação do estado nutricional das plantas: princípios e aplicações. 2. ed. Piracicaba: Associação Brasileira para pesquisa da Potassa e do Fosfato, 1997. 319 p.

NOVAIS, R. F.; ALVARES V.; V. H.; BARROS, N. F.; FONTES, R. L. F.; CANTARUTTI, R. B.; NEVES, J. C. L. Fertilidade do solo. 1 ed. Viçosa: Sociedade Brasileira de Ciência do Solo, 2007. 107p.

PIOTTO, F. A.; PERES, L. E. P. Base genética do hábito de crescimento e florescimento em tomateiro e sua importância na agricultura. Ciência Rural, Santa Maria, v. 42, n. 11, p. 1941-1946, 2012.

http://dx.doi.org/10.1590/S0103-84782012001100006

QUINTERO, J. M.; ENAMORADO, S.; MAS, J. L.; ABRIL, J. M.; POLVILlO, O.; DELGADO, A. Phosphogypsum amendments and irrigation with acidulated water affect tomato nutrition in reclaimed marsh soils from SW Spain. Spanish Journal of Agricultural Research, Madri, v. 12, n. 3, p. 809-819, 2014. http://dx.doi.org/10.5424/sjar/2014123-5273

RAMOS, Anamaria Ribeiro Pereira. Produtos de efeitos fisiológicos no desenvolvimento de plantas de tomate 'Giuliana', na produção e pós-colheita de frutos. 2013. 147 f. Tese (Doutorado em Agronomia: Horticultura)-Universidade Estadual Paulista, Faculdade de Ciências Agronômicas, Botucatu, 2013.

ROOSTA, H. R.; HAMIDPOUR, M. Effects of foliar application of some macro- and micro-nutrients on tomato plants in aquaponic and hydroponic systems. Scientia Horticulturae, Amsterdam, v. 122, n. 3, p. 396402, 2011. http://dx.doi.org/10.1016/j.scienta.2011.04.006

SHAH, M. A.; KHAN, A. I.; AWAN, F. S.; SADAQAT, H. A.; BAHADUR, S.; RASHEED, A.; BALOCH, F. S. Genetic diversity of some tomato cultivars and breeding lines commonly used in Pakistani breeding program. Turkish Journal of Agriculture - Food Science and Technology, Ankara, v. 3, n. 3, p. 126-132, 2015. 
SILVA, C. R.; VASCONCELOS, C. de S.; SILVA, V. J.; SOUSA, L. B.; SANCHES, M. C. Crescimento de mudas de tomateiro com diferentes telas de sombreamento. Bioscience Journal, Uberlândia, v. 29, n. 1, p. 1415-1420, 2013.

SILVA, F. A. S.; AZEVEDO, C. A. V. Versão do programa computacional Assistat para o sistema operacional Windows. Revista Brasileira de Produtos Agroindustriais, Campina Grande, v. 4, n. 1, p. 71-78, 2002. https://doi.org/10.15871/1517-8595/rbpa.v4n1p71-78

SILVA, J.; GUEDES, I. M. R.; LIMA, C. E. P. Adubação e nutrição. In: CLEMENTE, F. M. V. T.; BOITEUX, L.S. (Ed.). Produção de tomate para processamento industrial. Brasília: Embrapa, 2012. p. 105-127. 